\title{
STRATEGIZING FOR DISTRIBUTED KNOWLEDGE MANAGEMENT
}

\author{
MICHAEL HOLM LARSEN and MOGENS KÜHN PEDERSEN \\ Department of Informatics, Copenhagen Business School, Denmark
}

\begin{abstract}
Knowledge management is rarely found in a strategy context. Although some companies already have introduced the role of a chief knowledge officer, knowledge management is not treated as a strategic endeavour. Furthermore, contributions from an academic point of view are scarce in the field of the strategic issues of knowledge management. This paper contributes with some insight in pointing out the strategic question that knowledge management might provide answers for: The efficiency issue of strategic positioning. Furthermore, the paper emphasises the distinction between symmetric and asymmetric incentives in business relations, and on this basis identifies the notion of Distributed Knowledge Management as a means for creating efficiency strategies with symmetric incentives in business relations leveraging on information and communication technology exploitation. In this way a strategic agenda for knowledge management is identified.
\end{abstract}

\section{INTRODUCTION}

What kind of knowledge management activities is undertaken in companies? Are knowledge management projects merely considered as just another information technology or information system project? Has knowledge management actually reached the strategic agenda? Where does knowledge management fit in the strategic process? These are some of the questions that might be considered in relation to current practice of knowledge management in industry as well as in academia.

With the introduction of the notion of a "CKO", i.e. a chief knowledge officer (Davenport and Prusak 1998, Earl 1999), knowledge management is brought into the boardroom of companies - although the companies primarily are large firms. 
According to Earl \& Scott (1999) CKO's have two principal design competencies, i.e. that they are technologists meaning that they are able to understand which technologies can contribute to capturing, storing, exploring, and sharing knowledge, and they are environmentalists meaning that they have the ability to create social environments that stimulate and facilitate arranged and chance conversations or able to develop events and processes to encourage deliberate knowledge creation and exchange.

One reason why knowledge management from a strategic point of view is not diffused into most companies might be because there is little known about what strategic issues and questions knowledge management actually attack.

In practice knowledge management is rarely considered in a strategy context, and also little academic guidance is provided in literature. So far knowledge management is primarily treated as a tactical or an operational issue (Ruggles 1998, Davenport et al. 1998).

This paper provides some arguments on the kind of strategic questions where a knowledge management answer might prevail.

\section{KNOWLEDGE MANAGEMENT - TACTICAL AND OPERATIONAL PROJECTS}

What kind of knowledge management activities is undertaken in companies? Are knowledge management projects merely considered as just another information technology or information system project? Has knowledge management actually reached the strategic agenda? Where does knowledge management fit in the strategic process? These are some of the questions that might be considered in relation to current practice of knowledge management in industry as well as in academia.

With the introduction of the notion of a "CKO", i.e. a chief knowledge officer (Davenport and Prusak 1998, Earl 1999), knowledge management is brought into the boardroom of companies - although the companies primarily are large firms.

Ruggles (1998) has outlined a research agenda for knowledge management. He suggests a number of knowledge management activities, which are found in companies. The knowledge management activities are regarded from a process perspective of what can be managed about knowledge. These processes are: Generating new knowledge, accessing valuable knowledge from outside sources, using accessible knowledge in decision making, embedding knowledge in processes products, and/or services, representing knowledge in documents, databases, and software etc., facilitating knowledge growth through culture and incentive, transferring 
existing knowledge into others parts of the organisation, and measuring the value of knowledge assets and/or impact of knowledge management.

This research agenda is representative for most academic studies in knowledge management (e.g. Drucker 1988, Tampoe 1993, Wiig 1993, 1994, 1995, Davis \& Botkin 1994, Miles et al. 1998, Demarest 1997, Ruggles 1998, Jordan \& Jones 1997, Zack 1998, and Davis 1998). The list of knowledge processes shows that academia has focused on tactical and operational issues of knowledge management.

As this is the dominating research stream, the criteria for successful projects are not surprisingly also on a tactical or operational level. Davenport et al. (1998) suggest the eight most import criteria as being: Link to economic performance or industry value, technical and organisational infrastructure, standard, flexible knowledge structure, knowledge-friendly culture, clear purpose and language, change in motivational practices, multiple channels for knowledge transfer, and senior management support.

Although Davenport et al. (1998) point out the importance of linking a project to economic performance or industry value, this does not provide any substantial insight into how the knowledge management is related to the strategy, as focus primarily is on financial cost-benefit analyses.

We find the same conclusion regarding emphasis on tactical and operational issues of knowledge management when looking at the projects currently undertaken by companies. These projects are (Ruggles 1998): Creating an intranet, data warehouse/knowledge repository, implementing decision support tools, implementing GroupWare to support collaboration, create networks of knowledge workers, map sources of internal expertise, establish new knowledge roles, and launch new knowledge-based products or services

Earl (1999) argues that the firms need to have an information business mindset in their strategy making. Hence, Earl proposes firms to consider a convergence across industries towards the "information business". This raises three issues for business strategy making (Earl 1999, p. 163) which we here have related to knowledge management:

- "IT developments, threats and opportunities have to be included in strategy formation" In the knowledge management approach technologies and associated practices take precedence over a traditional value chain approach. IT is not only applied but built to fit information needs within the company and in between business partners.

- "The value creation potential of information has to be included in strategy formation." Knowledge management makes a difference to management decision when founded on business environmental attributes highly relevant to competitive advantage of products and processes. 
- "The future has to be brought back into strategy-making in order to analyse, anticipate, and prepare for the information age." In the case of knowledge management, information anticipation being associated with adding specific information to environmental knowledge enhances the strategic-making capacity of management.

This motivates the research method of the paper. First, we will revisit the knowledge management literature from an ontological point of view because this might bring some insight to the general perspectives that need to be considered in a strategic context. Second, in order to identify strategic issues of knowledge management, we will provide the basic strategic questions to be answered in strategic positioning of the company. From this literature review a framework for "Strategizing for the Digital Business" is established combining strategic position directions and incentive strategies.

\section{KNOWLEDGE MANAGEMENT ONTOLOGY AND REPOSITORIES}

Knowledge management represents issues reflecting the need for solutions of routines insufficiently supported or supportable by the organisational structures of modern business. The scope of knowledge management encompasses individual competence and organisation memory, knowledge creation from tacit to explicit knowledge and the role of organisations in facilitating the creation of knowledge (Nonaka 1994). The ontology of knowledge management (KM) stated by Nonaka and Takeuchi (1995) is the individual, organisational and interorganisation domains.

The capability of information technology to serve human purposes using symbols is an integrated part of knowledgeable human behaviour. Information technology in this regard is a knowledge technology that processes meaningful symbolic behaviour to manage extended economic organisations (Konsynski 1993, Pedersen 1996).

In each of the three domains the knowledge aspect that IT supports is analysed. The reason why information technology is considered in this section is the appreciation that IT no longer solely should be treated as an enabler of business processes. In fact, IT in it self hold promises in a strategic scenario that the company might opt for.

The ontology of knowledge management is:

The individual domain: Learning from Japanese manufacturing quality models has inspired a new interest in knowledge creation and sharing (Nonaka 1994, Nonaka et al. 1994, Nonaka and Takeuchi 1995, Nonaka and Konno 1998, Lincoln et al. 1998). In these models knowledge is created within the corporation as a part and parcel of a co-operation process between 
workers and departments. Polanyi $(1962,1966)$ provided the view of tacit and explicit individual knowledge. Nonanka and Konno's (1998) contextual knowledge creation in an organisational framework placed knowledge in a collective memory as social knowledge also known from Spender's view of social or organisational knowledge (Spender 1996). Whatever the industry, the social knowledge is achievable given the proper organisation is provided for, to process tacit knowledge (Takeuchi and Nonaka 1986).

In spite of reckoning tacit knowledge the promises of KM quickly move on to praise the value of explicit knowledge from individuals made available to the organisation after proper structuring and indexing of items. Creating the organisation's knowledge source is adamant to ensuring competitive viability of the company in adverse times when key personnel may leave for better performing competitors. That part of their knowledge that has been objectified into a knowledge repository remains with the company and thus confirms the idea of a pool of collective knowledge. This calls for establishing a knowledge repository.

The organisational domain: Knowledge management makes a public issue of what had previously been an asset of the individual member. The individual's knowledge consists in a mix of acquired formal qualifications and of job training as the merit of competence (Zuboff 1988). Today, knowledge is an asset when shared with other employees at the level of knowledge rather than at the level of functional tasks or as the product outcome of the division of labour. Thus it is the interchange of knowledge qua knowledge that represents the significant change in the management of knowledge from previous ways of managing knowledge. Ultimately, this implies to see the firm as a distributed knowledge system (Tsoukas 1996).

In recent years, competition has increasingly ruled out this knowledge management strategy and at the same time brought to the attention of management the opportunities for a focused use of information technologies for knowledge acquisition and dissemination within the organisation (Ciborra and Andreu 1996, Borghoff 1997, Davenport and Prusak 1998).

The following models moved on to offer a knowledge repository much inspired by enterprise resource planning models and the concept of centralised, corporate databases. In these models we find information quality issues along with best practice objectives that take knowledge across functional entities, between divisions or subsidiaries to make knowledge an organisational asset (Davenport and Klahr 1998). Disseminating knowledge was a matter of information retrieval and acquisition by each user as (s)he saw fit. Little or no decision support was offered from these repositories. What they offered were results of previous learning that only could be accessed if known to exist. 
The inter organisation domain: A third kinds of models moved on to widen the scope of knowledge management by including business partners in a broader network of knowledge exchange. The supply chain attracted attention with its scope for increase of overall efficiency (Anderson et al 1997). In manufacturing and in particular in biotechnology and pharmaceutical industries the core capabilities of companies are based increasingly on knowledge-seeking and knowledge-creation. Learning about new innovation opportunities requires the companies to participate in technical communinities and building interorganizational linkages critical to the diffusion of knowledge, learning and technology development (Powell 1998).

The linear model of a knowledge flow of the demands of customers to dealers and distributors did not transform into value-added knowledge before considering the advantage from using the World Wide Web using rich information representations. In particular manufacturing and service suppliers in customer support knowledge took advantage of the Internet in moving knowledge beyond organisational boundaries (El Sawy and Bowles 1997, Hagel and Rayport 1997, Venkatraman and Henderson 1998).

Today, the distinction between knowledge management in manufacturing and in professional services may seem to be overridden by the experience of knowledge management projects crossing previously relevant lines of demarcation (Krogh and Roos 1996, Krogh et al. 1997and1998, Davenport et al. 1998, Ruggles 1998, Alavi and Leidner 1999). The classic questions of $\mathrm{KM}$ were how to motivate specialists to share their knowledge (Tampoe 1993), how to make employees capable to share knowledge (Ciborra and Andreu 1998), how to balance historical knowledge with current knowledge through "organisational learning" (Nonaka 1994) or through codification changes (Hansen et al. 1999). Another set of classic questions we are facing are the questions which and how to create incentive schemes for the exchange of knowledge (or just data) with various business partners. The collaboration tends to create clusters of companies working together more intensively than with others that are excluded from the intensive knowledge interchange (Powell 1998). The network perspective receives increasing interest in the management literature as "the future competition is not between companies, but between networks" (Kotler 1994).

The traditional dichotomy of acquiring information either in reactive mode (El Sawy and Pauchant 1988) with a specific decision to make or in proactive mode to scan and monitor the environment to detect problems requires a different decision management. Between the two we find a network of interdependent decision-makers all acting on information specificity that derives from knowledge specificity and time specificity taking advantage of computer networks (Choudhury and Sampler 1997). 
Knowledge management therefore contemplates issues found in network theory exploring "co-specialised assets, joint control, and collective purpose" (Alstyne 1997:86).

The sequel to these business challenges has been the application of information technologies first represented in the acquisition of knowledge in a knowledge repository and later represented in network models like intranet and extranet (Davenport and Prusak 1998, Scott 1998). Knowledge management is bound to rely upon information technologies including networks, the technologies of processing, transmission and storage. On the one hand because these technologies continuously experience diminishing costs compared to wages and capital equipment and on the other hand because the organization of business is increasingly becoming one of interconnected networks of expertise and competence that require extensive collaboration across company boundaries. These forms of operations now challenge the concept of an enterprise repository that gives no access for the collaborating partners. How relevant and how representative of the knowledge creation will an enterprise repository become in a world of interorganizational knowledge linkages? Extranets are collaborative in principle and may therefore develop into the business partners co-specialized knowledge assets.

This article suggests that the rise of knowledge management should be tempered by the concomitant rise of decision support systems, though in a new framework, viz. the distributed knowledge management. The model of supply chain management relates a significant share of all trade to opportunities of knowledge management for efficiency purposes thus representing a significant part of all business models. The supply chain network has been shown to benefit from information technology in the order fulfilment process (Strader et al. 1998). Unlike previous, often hypothetical discussions of virtual organisations, a supply chain network decision support system provides an illustration of a robust knowledge based structure where the knowledge exchange enhance the performance efficiency of all participating in the network.

The model to be presented differs in a significant respect from other models catering only for knowledge relations discarding the specific nature of network business relations though stressing the decision support capability (Sridhar 1998). We argue that the exchange of asymmetric, specific knowledge in a network economy generates among all the participants a performance superior to that achieved without distributed knowledge networks.

Knowledge management is sparsely treated in the strategic literature although the focus in resent years is intensified, cf. Zack (1999), Carneiro (2000), Helfat \& Raubitschek (2000), Davenport \& Völpel (2001), Bollinger 
\& Smith (2001), McEvily \& Chakravarthy (2002), Mcnamara et al. (2002), Miller (forthcoming), and Tsang (forthcoming). Moreover, developing a knowledge management stand in the strategic positioning literature is not yet established.

Summing up this section, the review of the knowledge management ontology point to the importance that a company should be defined not only based on internal capabilities but in relation to the network in which it operates. From here the information system requirements can be derived.

\section{KNOWLEDGE MANAGEMENT IN STRATEGIC POSITIONING}

Strategy can be regarded from various points of view. An established point of view is the "Who, What, How" framework (Abell 1980). This framework proposes that the strategic position of a company is the sum of target customers (who), products and services (what), and the optimal way the company furnishes these efficiently (Markides 1997, 1998, 1999). This line of thought is by Applegate (2001) extended to encompass the evolution of an e-business strategy by considering the four issues of enhancement, extension, expansion and exit (p. 77). By enhancement is ment adding functionality or improving a product or service that is currently offered. Extension addresses the adoption of new business models or entering new businesses. Expansion means adding products and services within the existing business. Finally, exit point the options of eliminating a product or serviceline or leaving a business.

The competitive dynamics of markets impose upon management to follow-up on changing market structures and competitor behaviour, demanding on-going strategizing. Management has to consider regularly in which business they operate as well as the efficiency with which they operate, for example by reconsidering their core competencies in terms of opportunities for sharing, reusing or expanding competencies (Markides 1997).

In setting business right for strategizing the predominant guideline has been the value chain (Porter 1985) and the e-business imperative of the competitive forces of an industry (Porter 2001). The scope of this line of analysis is elaborated through complementors, which are participants in the value network from whom the customer buys complementary products or services, or to which suppliers sell complementary resources, cf. Ghemawat et al. (2001). Beyond the positioning framework Porter now stipulates the competitive advantages derived from clusters (Porter 1990, 1998a, 1998b): "Clusters are geographic concentrations of interconnected companies and 
institutions in a particular field" and "encompass an array of linked industries and other entities important to competition." While the geographic concentration is a codetermining factor of a cluster it is also "an alternative way of organising the value chain." Repeated exchanges, better coordination and trust "mitigate the problems inherent in arm's-length relationships without imposing the inflexibility of vertical integration or the management challenges of creating and maintaining formal linkages such as networks, alliances, and partnerships" (Porter 1998b: 78). The mutual benefits of clusters derive from this "organisational form that offers advantages in efficiency, effectiveness, and flexibility." Porter identifies the cluster effects upon competition as three: increase the productivity of companies based in the area; drive the direction and pace of innovation; stimulate the formation of new businesses that expand and strengthen the cluster itself. The cluster effects allow "each member to benefit as if it had greater scale or as if it had joined with others formally - without requiring it to sacrifice its flexibility."

The strategic option for knowledge management in clusters is to support business procurement, to exchange specialised information, and to offer complementarities like product complements and co-ordination of activities across companies' optimising on collective productivity (Porter 1998b).

The agenda of knowledge management previously limited to tactical and operational issues is now raising to strategic issues of the business. The Internet revolution has made network reconfiguration in Intranet and Extranet an issue in formulating digital based business strategies (Venkatraman and Henderson 1998). These strategies require a new knowledge management strategy: Which knowledge, to whom, and in which way?

In table 1 the strategic positioning framework of product-market and efficiency is associated with the nature of the incentive strategy. The asymmetric incentive strategy follows from unequal positions in the value chain reflecting strategies of competitive advantage (Porter 1980, 1985). The strength may be based in cost advantages, brands or other vehicles for differentiation in the market. The symmetric incentive strategy follows from the recognition of complementarities. The advance of the cost efficiency or strategic positioning of one partner benefits the other partners. In terms of knowledge management the advance of one partner depends upon the others and vice versa. There is a mutual incentive to enable the other partner to succeed because that facilitates and increases the probability of success for one self. Collaboration between companies at various levels of expertise reaches into strategic issues of product development and market strategies. 


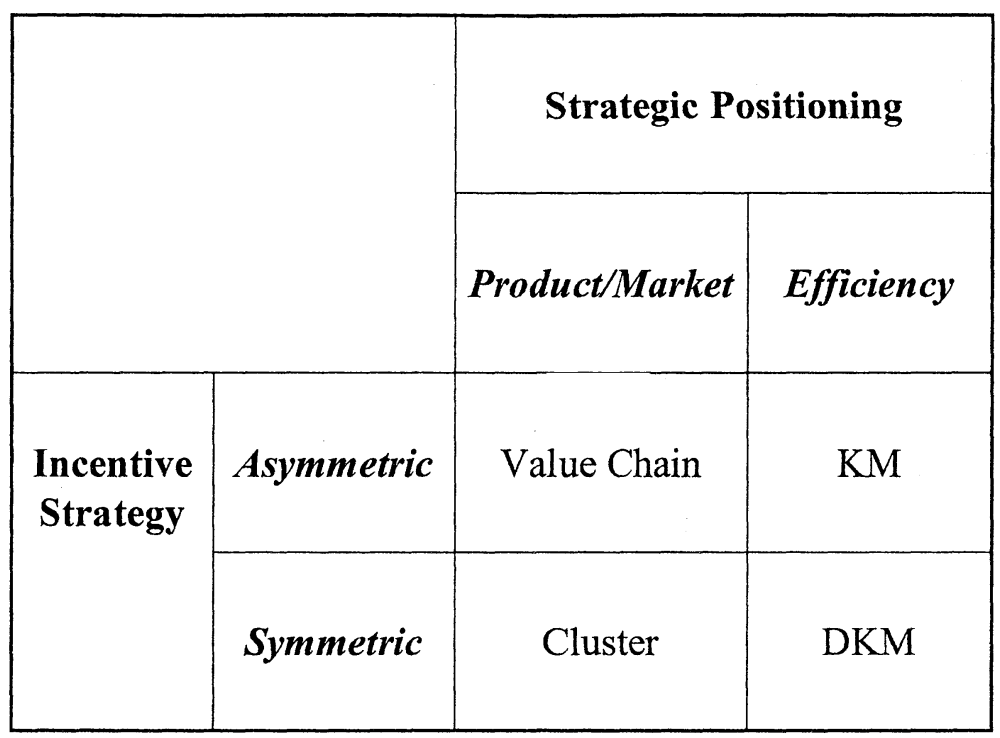

Table 1. Strategizing for the Digital Business.

Moving beyond the boundaries of the firm into the extended enterprise (Konsynski 1993) elevates the virtual organising of business into a knowledge based strategy for a "dynamic portfolio of relationships to assemble and co-ordinate the required assets for delivering value to the customers" (Venkatraman and Henderson 1998:33). Their principles governing strategizing network reconfiguration cannot be found in a conception of knowledge management as purely an internal business affair. Business-to-business networks transcend the conventional image of value chains creating a complex exchange of specific information and in particular of specific knowledge (Choudhury and Sampler 1997).

In table 1 the concomitant of incentive strategies for knowledge management is also highlighted.

The centralised knowledge creation model promotes the idea of making knowledge available to the whole organisation as the purpose of knowledge management (Nonaka 1994, Nonaka et al. 1994, Nonaka and Takeuchi 1995, El Sawy and Bowles 1997, Favela 1997, Davenport and Klahr 1998). Here knowledge management (KM) faces the challenge how to ensure a dynamic updating of knowledge. The decision-making qualities of a relevant and timely information for decision support come to the fore in the concept of information specificity (Choudhury and Sampler 1997).

The alternative to a centralised knowledge management model, a distributed knowledge management model, generates knowledge amongst decision-makers in interdependent businesses on a continuous basis while 
redistributing the outcome for a time efficient knowledge use (Pedersen \& Larsen 2001). The symmetries in knowledge and time specificity of the decision-makers ensure that knowledge creation in an actor network is an incentive compatible exchange of knowledge. Actor network theory captures the idea of a heterogenous, bottom-up and dynamic change of collaboration determined by the intermediary (here the specific information interchanged for knowledge creation) of the network (Callon 1991, Walsham 1997, Hull et al. 1999). Hence, DKM becomes a strategic issue as the company needs to decide "how" (cf. Abell 1980) to position itself in the value network in which it operates.

An example illustrating the strategic role of knowledge management is the findings by Granstrand et al. (1997). The study of 500 companies showed that the product portfolio compared to the portfolio of technologies could be described by the concept of distributed competences reflecting that their selection of a knowledge strategy exceeds the product strategy.

The centralised KM model consists in a conversion from individual, knowledge specificity into organisational, collective knowledge made available to all individuals where each individual user on an ad hoc basis converts the global knowledge into local decision support. In contrast, the distributed $\mathrm{KM}$ model requires another conversion. The focus is on the exchange of specific knowledge to network actors in a mutual value-adding network. Each actor appropriates information and submits enhanced information that in return becomes enhanced by other network actors at other destinations and thus return to the originator more valuable than when originated.

The actor network realises the exchange of a knowledge and time specific information thus taking responsibility for making knowledge creation available for decision by all actors in the network. The latter process also makes for the difference between a centralised KM system that is passive in regard to decision making and an active distributed decision support system that takes advantage of the knowledge specificity related to the different actors. And finally knowledge creation in terms of knowledge specificity encompasses both tacit and explicit knowledge since the same individuals or teams that create knowledge apply it (Polanyi 1962, 1966, Spender 1996). The emergent knowledge co-located with the actor results from acquired knowledge from the network merged with local, specific knowledge. Therefore emergent knowledge resides with the actor and does not have to cross the organisational boundaries of the collaborators. Only specific knowledge items are passed on in the actor network. This accounts for the symmetric incentive character of the network DKM model. Further, the collaboration between partners reflects their different roles and contributions reinforcing the economic complementarities of the cluster in 
which they participate. The strategic implications for product improvements and innovations follow.

\section{CONCLUSION AND PERSPECTIVES}

Knowledge management is seldom put into a strategy context. Although some companies already have introduced the role of a chief knowledge officer, knowledge management is rarely treated as a strategic endeavour. Also from an academic point of view few contributions are made in the field of the strategic issues of knowledge management.

This paper reviews the ontology of knowledge management as a basic understanding for creating business scenarios. The result of this review shows that a company should be defined not only based on internal capabilities but in relation to the network in which it operates or should operate to generate knowledge and new complementarities.

The primary contribution of this paper is a suggestion towards the kind of strategic questions that knowledge management might answer. The conclusion is that knowledge management contributes in the efficiency issues of strategic positioning.

Furthermore, the paper emphasises the distinction between symmetric and asymmetric incentives in business relation, and on this basis identifies the concept of Distributed Knowledge Management as a means for creating efficiency strategies with symmetric incentives in business relations.

Based on the issues raised in the paper, future research might then approach research questions as how to create knowledge-based strategic scenarios, raising further questions of how to incorporate symmetric incentive schemes in business relations. And raise the following issues on how to create knowledge-based business models, and how to test the viability and efficiently/effectiveness of the knowledge-based business model.

\section{REFERENCES}

Abell, D. (1980). Defining the business: The starting point of strategic planning. Englewood Cliffs, New Jersey: Prentice-Hall.

Adam, F., Fahy, M., and Murphy, C. (1998). A framework for the classification of DSS usage across organisations. Decision Support Systems, 22, 1-13.

Alavi, M. and Leidner, D. E. (1999). Knowledge Management Systems: Issues, Challenges, and Benefits. Communications of the Association for Information Systems. Vol. 1, Paper 5 , January. 
Alstyne, M. van (1997). The State of Network Organisation: A Survey in Three Frameworks. Journal of Organisational Computing and Electronic Commerce. 7,2\&3) 83-151.

Anderson, E.; Day, G.; Rangan, V.K. (1997). Strategic Channel Design. Sloan Management Review, June. 59-69.

Applegate, L. (2001). E-Business Models - Making Sense of the Internet Business Landscape, pp. 49-101. In Dickson \& DeSanctis (2001).

Badaracco, Jr. Joseph L. (1991). The Knowledge Link. Harvard Business School Press. Boston, Mass.

Bollinger, A.S \& Smith, R.D. (2001). Managing organizational knowledge as a strategic asset. Journal of Knowledge Management. 5(1), pp. 8-18.

Borghoff, U.M. (1997). Information Technology for Knowledge Management. Journal of Universal Computer Science. 3(8), 835-842.

Callon, M. (1991). Techno-economic networks and irreversibility. In J. Law, ed. A Sociology of Monsters. Essays on Power, Technology and Domination. Sociological Review Monograph 38. London: Routledge.

Carneiro, A. (2000). How does knowledge management influence innovation and competitiveness? Journal of Knowledge Management. 4(2), pp. 87-98.

Chesbrough, H.W. and Teece, D. J. (1996). When is Virtual Virtuous? Organizing for Innovation. Harvard Business Review, 74, Jan-Feb. 65-73.

Choudhury, V. and Sampler, J. L. (1997). Information Specificity and Environmental Scanning: An Economic Perspective. MIS Quarterly, March 21(1) 25-53.

Ciborra, Claudio and Andreu, Rafael (1998). Organisational Learning and Core Capabilities Development: The Role of IT. in Information Technology and Organisational Transformation. Edited by R. Galliers and W.R.J. Baets. John Wiley and Sons Ltd.

Currie, W.L. \& Galliers, B. (1999). Rethinking Management Information Systems. Oxford University Press.

Davenport, T. and Prusak, L. (1998). Working Knowledge - How Organisations Manage What They Know. Harvard Business School Press, Boston, MA.

Davenport, T.H. \& Völpel, S.C. (2001). The rise of knowledge towards attention management. Journal of Knowledge Management. 5(3), pp. 212-222.

Davenport, T.H. and De Long, D.W. and Beers, M.C. (1998). Successful Knowledge Management Projects. Sloan Management Review. 39(2) Winter, 43-57.

Davenport, T.H. and Klahr, P. (1998). Managing Customer Support Knowledge, California Management Review 40(3) 195-208.

Davis, M.C. (1998). Knowledge Management. Information Strategy: The Executive's Journal. Fall, 11-22.

Davis, S. \& Botkin, J. (1994). The Coming of Knowledge-Based Business. Harvard Business Review. September-October, 165-170.

Demarest, M. (1997). Understanding Knowledge Management. Long Range Planning. 30(3), 374-384.

Dickson, G.W. \& DeSanctis, G. (2001). Information Technology and the Future Enterprise New Models for Managers. Prentice Hall.

Drucker, P.F. (1988). The Coming of the New Organization. Harvard Business Review. January-February, 45-53.

Earl, M.J. (1999). Strategy-Making in the Information Age. In Currie \& Galliers (1999), pp. 161-174.

Earl, M.J. and Scott, I.A. (1999). What Is a Chief Knowledge Officer? Sloan Management Review. Winter, Volume 40, No. 2. 
El Sawy, O.A. and Bowles, G. (1997). Redesigning the Customer Support Process for the Electronic Economy: Insights from Storage Dimensions. MIS Quarterly December 457483.

El Sawy, O.A. and Pauchant, T.C. (1988). Triggers, Templates and Twitches in the Tracking of Emerging Strategic Issues. Strategic Management Journal 9 (5) 455-473.

Evans, G.N. and Naim, M.M. and Towill, D.R. (1993). Assessing the Impact of Information Systems on Dynamic Supply Chain Performance. Logistics Information Management. 6(4), 15-25.

Favela, J. (1997). Capture and Dissemination of Specialized Knowledge in Network Organisations. Journal of Organisational Computing and Electronic Commerce 7 (2and3) 201-226.

Foss, N. J. (ed.) (1997). The Resource-based Perspective on the Firm. London: Routledge Kegan Paul.

Galbraith, J.R. and Lawler III, E.E. (1993). Organising for the Future. The New Logic for Managing Complex Organisations. San Francisco: Jossey-Bass Publishers.

Ghemawat, P. Collis, D.J. \& Pisano, G.P. \& Rivkin, J.W. (2001). Strategy and the Business Landscape: Core Concepts. Prentice Hall. Ghosh, A. K., 1998. E-Commerce Security. Weak Links, Best Defenses. Wiley Computer Publ. N.Y.

Granstrand, O., Patel, P.O. \& K. Pavitt (1997) Multi-technology Corporations: Why they have "distributed" rather than "distinctive" core competencies. California Management Review, 39 (4), Summer, pp. 8-25.

Hagel, J. and Armstrong, A. (1997). Net Gain: Expanding Markets Through Virtual Communities. The McKinsey Quarterly, 1, 140-153.

Hagel, J. and Rayport, J. (1997). The Coming Battle for Customer Information. Harvard Business Review, January-February, 53-65.

Hammer, M. (1996). Beyond Reengineering. Harper Collins Publishers. N.Y.

Hammer, M. and Champy, J. (1993). Reengineering the Corporation - A Manifesto for Business Revolution. Harper Collins Publishers, New York.

Hansen, M. T., Nohria, N. and Tierney, T. (1999). What's your strategy for managing knowledge? Harvard Business Review 77 (2) 106-116.

Hax, A. and Wilde II, D.L. (1999). A Delta Model: Adaptive Management for a Changing World. Sloan Management Review 40 (2) 11-28.

Helfat, C. E. \& Raubitschek, R.S. (2000). Product sequencing: co-evolution of knowledge, capabilities and products. Strategic Management Journal. 21(10-11), pp. 961-979.

Holland, C.P. (1995). Cooperative Supply Chain Management: the Impact of Interorganizational Information Systems. Journal of Strategic Information Systems. 4(2), 117-133.

Holtshouse, D. (1998). Knowledge Research Issues. California Management Review. 40(3), 277-280.

Huber, G. (1982). Organisational Information Systems: Determinants of Their Performance and Behavior. Management Science 28 (2) February. 138-155.

Hull, R.,V. Walsh, Green, K., and McMeekin, A. (1999). The Techno-Economic: Perspectives for Analysis and Intervention. Journal of Technology Transfer, 24. 185-195.

Johanson, J. and Mattsson, L.-G. (1987). Interorganizational relations in industrial systems: a network approach compared with the transaction-cost approach. International Studies of Management and Organisation. 17. 34-48.

Jordan, J. \& Jones, P. (1997). Assessing your Company's Knowledge Management Style. Long Range Planning. 30(3), 392-398.

Keen, P. G.W. (1986). Competing in Time. Ballinger Publ. 
Konsynski, B.R. (1993). Strategic Control in the Extended Enterprise. IBM Systems Journal, 32(1), 111-142.

Kotler, P. (1994). Marketing Management: Analysis, Planning, Implementation and Control. Prentice Hall.

Krogh, G. von and Nonaka, I. and Ichijo, K. (1997). Development Knowledge Activists. European Management Journal, 15(5), 475-483.

Krogh, G. von and Roos, J. (1996). Managing Knowledge - Perspectives on Cooperation and Competition. Sage, London.

Krogh, G. von, Roos, J. and Kleine, D. (1998). Knowing in firms - Understanding, Managing and Measuring Knowledge. Sage, London.

Larsen, M.H.; L.R. Franck, and Pedersen, M. Kühn. (1999). Frontline CALS - Extranet Enabled Support of Customer Relations Based on Product State Information. Proceedings of the 7th European Conference on Information Systems. Copenhagen, June, 302-319.

Leidner, D.E. (1999). Virtual partnerships in support of electronic commerce: the case of TCIS. Journal of Strategic Information Systems. 8(1) 105-117.

Lincoln, J. R. and Ahmadjian, C.L. and Mason, E. (1998). Organisational Learning and Purchase-Supply Relationships in Japan: Hitachi, Matsushita, and Toyota Compared. California Management Review. 40(3), 241-264.

Lomi, A. (1997). Markets with Hierarchies and the Network Structure of Organisational Communities. Journal of Management and Governance, 1, 49-66.

Markides, C.C. (1997). Strategic Innovation. Sloan Management Review 38(3) Spring, 9-23.

Markides, C.C. (1998). Strategic Innovation in Established Companies. Sloan Management Review 39(3) Spring 31-42.

Markides, C.C. (1999). A Dynamic View of Strategy. Sloan Management Review 40(3) Spring 55-63.

Mason-Jones, R. and Towill, D.R. (1997). Information Enrichment: Designing the Supply Chain for Competitive Advantage. Supply Chain Management. 2(4), 137-148.

Mason-Jones, R. and Towill, D.R. (1998). Time Compression in the Supply Chain: Information Management is the Vital Ingredient. Logistics Information Management. 11(2), 93-104.

McEvily, S.K. \& Chakravarthy, B. (2002). The persistence of knowledge-based advantage: an empirical test for product performance and technological knowledge. Strategic Management Journal. 23(4), pp. 285-305.

Mcnamara, G.M. \& Luce, R.A. \& Tompson, G.H. (2002). Examining the effect of complexity in strategic group knowledge structures on firm performance. Strategic Management Journal. 23(2), pp. 153-170.

Meier, J. (1995). The Importance of Relationship Management in establishing Successful Interorganizational Systems. Journal of Strategic Information Systems. 4(2), 135-148.

Miles, G. \& Miles, R.E. \& Perrone, V. \& Edvinsson, L. (1998). Some Conceptual and Research Barriers to the Utilization of Knowledge. California Management Review. 40(3), 281-288.

Milgrom, P. and J. Roberts (1992). Economics, Organisation and Management. Englewood Cliffs, N.J. Prentice-Hall International, Inc.

Miller, K.D. (forthcoming). Knowledge inventories and managerial myopia. Strategic Management Journal.

Nonaka, I. (1994). A Dynamic Theory of Organisational Knowledge Creation. Organisation Science, 5, 14-37.

Nonaka, I. and Konno, N. (1998). The Concept of "Ba": Building a Foundation for Knowledge Creation. California Management Review, 40(3), 40-54. 
Nonaka, I. and Byosiere, P. \& Borucki, C.C. \& Konno, N. (1994). Organisational Knowledge Creation Theory: A First Comprehensive Test. International Business Review. Special Issue on Knowledge in Organisations, Knowledge Transfer, and Cooperative Strategies. 3/4, 337-351.

Nonaka, I. and Takeuchi, H. (1995). The Knowledge Creating Company - How Japanese Companies Create the Dynamics of Innovation. Oxford University Press.

Pedersen, M.K. \& Larsen, M.H. (2001). Distributed Knowledge Management based on Product State Models - The Case of Decision Support in Health Care Administration. Decision Support Systems. Special issue on Knowledge Management. Volume 31, Number 1, pp. 139-158.

Pedersen, M.K. (1996). A Theory of Informations. The Business Cycle Model. Copenhagen. Samfundslitteratur.

Polanyi, M. (1962). Personal Knowledge: Towards a Post-critical Philosophy. University of Chicago Press, New York.

Polanyi, M. (1966). The Tacit Dimension. Anchor Day, New York.

Porter, M.E. (1985). Competitive Advantage. Free Press, N.Y.

Porter, M.E. (1990). The Competitive Advantage of Nations. Macmillan, N.Y.

Porter, M.E. (1998a). Clusters and the New Economics of Competition. Harvard Business Review. November-December 76(6) 77-90.

Porter, M.E. (1998b). The Adam Smith Adress: Location, Clusters, and the "New" Microeconomics of Competition. Business Economics. Washington, January 33(1) 7-13.

Porter, M.E. (2001). Strategy and the Internet, Harvard Business Review, March.

Powell, W.W. (1998). Learning from Collaboration: Knowledge and Networks in the Biotechnology and Pharmaceutical Industries. California Management Review, 40(3), 228-240.

Quintas, P. \& Lefrere, P. \& Jones, G. (1997). Knowledge Management: A Strategic Agenda. Long Range Planning. 30(3), 385-391.

Rayport, J.F. and Sviokla, J.J. (1995). Exploiting the Virtual Value Chain. Harvard Business Review, November-December, 75-85.

Riempp, G. and Nastansky, L. (1997). From Islands to Flexible Business Process NetworksEnabling the Interaction of Distributed Workflow Management Systems. Proceedings of the $5^{\text {th }}$ European Conference on Information Systems. Vol. 1, 481-496.

Ruggles, R. (1998). The State of the Notion: Knowledge Management in Practice. California Management Review. 40(3), 80-89.

Sampler, J. L. (1998). Redefining Industry Structure for the Information Age. Strategic Management Journal 19. 343-355.

Scott, J. E. (1998). Organisational Knowledge and the Intranet. Decision Support Systems. 23, 3-17.

Shapiro, C. and Varian, H. R. (1999). Information Rules. A Strategic Guide to the Network Economy. Boston: Harvard Business School Press.

Spender, J.C. (1996). Organisational Knowledge, Learning and Memory: Three Concepts in Search of a Theory. Journal of Organisational Change Management, 9, 63-78.

Spinardi, G. and Graham, I. and Williams, R. (1997). EDI in the Scottish Health Service: Inter-Organisational Systems and Inter-Organisational Change. Journal of Strategic Information Systems. 6(3), 251-263.

Sridhar, S. (1998). Decision Support using the Intranet. Decision Support Systems, 23, 19-28. Stalk, G. and Hout, T.M. (1990). Competing Against Time. N.Y. The Free Press.

Strader, T. J.; Fu-Ren Lin; Shaw, M.J. (1998). Information Infrastructure for electronic virtual organisation management. Decision Support Systems 23, 75-94. 
Swatman, P.M.C., Swatman, P.A., and Fowler, D.C. (1994). A model of EDI integration and strategic business reengineering. Journal of Strategic Information Systems. 3(1) 41-60.

Takeuchi, H. and Nonaka, I. (1986). The New Product Development Game. Harvard Business Review, January-February, 137-146.

Tampoe, M., (1993). Motivating Knowledge Workers - The Challenge for the 1990s. Long Range Planning. 26(3), 49-55.

Teece, D. J. Ed. (1987). The Competitive Challenge. Cambridge. Mass.

Teece, D. J., (1987). Profiting from technological innovations: Implications for integration, collaboration, licensing and public policy. in Teece,1987).

Tsang, E.W.K. (forthcoming). Acquiring knowledge by foreign partners from international joint ventures in a transition economy: learning-by-doing and learning myopia. Strategic Management Journal.

Tsoukas, H. (1996). The firm as a distributed knowledge system: A constructionist approach. Strategic Management Journal, 17, Winter, 11-25.

Tunc, E.A. and Gupta, J.N.D. (1993). Is Time a Competitive Weapon Among Manufacturing Firms?. International Journal of Operations and Production Management. 13(3), 4-12.

Venkatraman, N. (1994). IT-Enabled Business Transformation: From Automation to Business Scope Redefinition. Sloan Management Review, 35, Winter 73-87.

Venkatraman, N. and Henderson, J.C. (1998). Real Strategies for Virtual Organizing. Sloan Management Review, 40 (1) Fall, 33-48.

Walsh, P. and Koumpis, A. (1998). Introducing the Concept of Information Supply Chains: the Buddy Project. Logistics Information Management. 11(2), 74-79.

Walsham, G. (1997). Actor-Network Theory and IS Research: Current Status and Future Prospects, in Information Systems and Qualitative Research. A.S. Lee, J. Liebenau, and J.I. DeGross (eds.), Chapman \& Hall, London. 466-480.

Wang, E. T.G. and Barron, T. (1997). Computing services supply management: Incentives, information, and communication. Decision Support Systems 19, 123-148.

Webster, J. (1995). Networks of Collaboration or Conflict? Electronic Data Interchange and Power in the Supply Chain. Journal of Strategic Information Systems. 4(1), 31-42.

Wernerfelt, B. (1984). A Resource-based view of the firm. Strategic Management Journal 5, $171-180$.

Wiig, K.M. (1993). Knowledge Management Foundations: Thinking About Thinking - How People And Organizations Create, Represent And Use Knowledge. Schema Press, Arlington.

Wiig, K.M. (1994). Knowledge Management - The Central Focus for Intelligent-acting Organizations. Schema Press, Arlington.

Wiig, K.M. (1995). Knowledge Management Methods - Practical Approaches to Managing Knowledge. Schema Press, Arlington.

Williams, T. (1997). Interorganisational Information Systems: Issues Affecting Interorganisational Cooperation. Journal of Strategic Information Systems. 6(3), 231-250.

Williamson, O. E. (1985). The Economic Institutions of Capitalism. New York: The Free Press.

Williamson, O. E. (1986). Economic Organization. Brighton: Wheatsheaf Books Ltd.

Williamson, O. E. (1994). Transaction cost economics and organization theory. In Smelser, N.J. and Swedberg,R. (eds) The Handbook of Economic Sociology. Princeton U P. 77107.

Winter, S. (1987). Knowledge and Competence as Strategic Assets. In Teece, D. (edit.), (1987). The Competitive Challenge. New York, Harper and Row. 
Zack. M.H. (1998). An Architecture for Managing Explicit Knowledge. Proceedings of the 6th European Conference on Information Systems, Aix-en-Provence, France, June 4-6, pp. 86-99.

Zack. M.H. (1999).Developing a Knowledge Strategy. California Management Review. 41(3), Spring, pp. 125-145.

Zuboff, S. (1988). In the Age of the Smart Machine. 